\title{
Revisiting the notion of "sustainable tourism" for legal regulation purposes in Russian Federation and Republic of Belarus
}

\author{
Vitali Maksimeniuk ${ }^{1}$, and Roza Timakova ${ }^{2, *}$ \\ ${ }^{1}$ Faculty of Law of Polotsk State University, Blokhina Str., 29, 211446 Novopolotsk, Republic of \\ Belarus \\ ${ }^{2}$ Ural State University of Economics, 8 Marta Str., 62, 620144 Ekaterinburg, Russia
}

\begin{abstract}
The article considers theoretical aspects of a most important contemporary issue, i.e. modern approaches to sustainable tourism. The study shows the main relationships of the phenomenon with sustainable economic and social development. The research results in identification of the essential characteristics (signs) of sustainable tourism, i.e. for the legal regulation purposes. The concept of "sustainable tourism" for deliberate influence of the state on public relations in tourism using special legal means and methods was defined. The conclusions may improve the current regulatory framework of the Russian Federation and the Republic of Belarus. Changes and additions to the national laws on tourism are suggested and justified. They relate to introduction of the definition of the concept of "sustainable tourism" and inclusion of the principle of sustainable tourism development.
\end{abstract}

\section{Introduction}

There existed an idea that tourism is a branch of economy that maintained its proportional growth, despite crises, changes of political situations and development vectors [1]. However, global economic and social trends impact on the sustainable development of tourism. The pandemic of coronavirus infection differs from many world crises processes. It has affected sectors of the economy, i.e. the tourism industry. So, the field is undergoing serious difficulties. According to the United Nations World Tourism Organization (UNWTO), as of July 2020, the coronavirus pandemic caused losses of \$ 320 billion to global tourism. It is more than three times the losses in this sphere after the economic crisis of 2009 [2]. The current conditions of uncertainty change tourists' preferences due to the massive closure of borders to ensure security and prevent the spread of infection. There is reorientation to domestic tourism that may further help to "create a model for sustainable tourism development that will satisfy the needs of foreign and domestic tourists and the region as a whole, will strengthen its reputation and positive image" [3].

The current situation requires consideration of the concept of "sustainable tourism" to adopt and test decisions identical to those based on a situational analysis taken by different states in conditions of general tension. 
Meanwhile, the prospects for the development of the public relation branch are evident. The adopted Concept of the National Strategy for Sustainable Development of the Republic of Belarus for the period to 2035 - Section 4.8 "Tourism Industry" - includes conditions for the further development of tourism. The Russian Voluntary National Review on the Implementation of the Agenda for Sustainable Development for the period to 2030 describes the main guidelines for the sustainable development of various sectors of the economy at the national level, i.e. the tourism industry [4].

The objectives of the research are to study theoretical aspects of sustainable tourism and its characteristics. The purpose of the research is to develop a definition of the category for legal regulation purposes of the Russian Federation and the Republic of Belarus.

\section{Materials and Methods}

The materials for the study were the current regulatory legal acts and official documents of the Government of the Republic of Belarus and the Government of the Russian Federation, and scientific research literature. General scientific theoretical and empirical research methods were applied for the comparative analysis and consolidation of the results. The research approach is aimed to reduce legal uncertainty regarding the terminology of sustainable tourism development. The approach determines the need for the methodological approach to standardize the terminology.

\section{Results and Discussion}

The phenomenon of sustainable tourism is significant from the economic and from any sphere of social relations point of view, i.e. the legal one.

The concept of "sustainable development" has no plain meaning, so, there is no an acceptable definition of sustainable tourism yet.

For the first time the mention of the concept of sustainable development appeared in the "World Environment Protection Strategy" - an international legal act of the World Conservation Union (1980), in which the following definition was given: "Sustainable development is a process in which development occurs without harming resources and their depletion, which makes development possible. This is typically accomplished by either managing resources so that they can be renewed at the same rate as they are being used, or by switching from slow-renewing resources to fast-renewable ones. Taking into account this approach, resources can be used by both future and present generations" [5].

The Hague Declaration on Tourism adopted by the Inter Parliamentary Union (IPU) and the World Tourism Organization (WTO) in 1989 [6] indicates that tourism and nature are closely interdependent. So, actions should be taken to help the integrated planning of tourism development in accordance with the concept of "sustainable development". The concept is mentioned in the Report of the World Commission on Environment and Development (Brundtland Report) and in the report "Environmental Perspective to the Year 2000 and Beyond" of the United Nations Environment Program (UNEP). The both reports underwent procedures of adoption by the UN General Assembly.

The UN Conference on Environment and Development in Rio de Janeiro in 1992 at the Earth Summit was a very important exchange of views on the harmonious development of society and nature. The conference surpassed similar events in the number of heads of state participating in it. Those involved to the conference adopted a comprehensive program of action, the so-called "Agenda 21", which concluded the opposite to the concept of "limits to growth" [7]. 
20 years after the adoption of the "Rio Declaration" - in June 20-22, 2012 - the United Nations held the "Rio +20 " Conference. The materials of the conference included more extended conditions of the concept of sustainable development.

Tourism is developed in accordance with the Sustainable Development Goals (SDGs), in particular SDG 8 (promotion of sustained, inclusive and sustainable economic growth, full and productive employment and decent work for all); SDG 12 (insurance of sustainable consumption and production patterns); SDG 14 (conservation and sustainable use of the oceans, seas and marine resources for sustainable development) [8]. The term "sustainable tourism" appears within the framework of target 12.b (development and implementation of tools for monitoring the impact of sustainable tourism on sustainable development).

S.V. Smirnov notes that [9] to monitor the SDGs achievement in the tourism industry certain indicators are used. They are change in the number of tourists, calculated indicators of permissible tourist load, safety of forest and water resources, waste management rules, employment rate in the tourism sector, level of economic efficiency, etc.

As there are not much significant discussions about the essence of the concept of "sustainable tourism", the opinions of researchers on the specific feature differ: should this phenomenon be considered a type of tourism?

E.V. Moshnyaga supposes that sustainable tourism is not a type of tourism but a philosophical concept or an ideological approach to the development of tourism in the future, where the natural, cultural and social environment of the destination is preserved [10]. I.N. Yakhnovets considers the phenomenon not as a type, but as a direction of tourism development, which is based on the principles of the concept of sustainable development [11]. Unlike them, O.V. Pirogova and A. Yu. Pirogova suggest that sustainable tourism is a set of relevant relations and phenomena. They define sustainable tourism as a type of tourism presupposing temporary trips of individuals for various purposes [1].

E.M. Maksarova separates the concepts of "sustainable tourism development", "sustainability in tourism" and "sustainable tourism". The first category relates to the development of tourism that focuses on a long-term period and a balance of various development goals and interests of the parties involved in the process based on rational use of tourism resources [12].

The concept, having direct connection with sustainable tourism, may be reasonably considered one of the principles of tourism, i.e. the principle of state regulation of the tourism industry. In the second case, the positive overall balance of the various impacts of tourism, as well as visitors (tourists), on each other is considered.

The "sustainable tourism" is a type of tourism in which the optimal use of environmental resources is ensured, and the socio-cultural characteristics of the host communities are supported [12].

Some authors believe that sustainability should be regarded from the point of view of intensity and efficiency of the search structure, the development of compromise decisions, consideration of the interests of developing systems under conditions of existing uncertainty [13].

UNWTO and WTTC formulated the definition and characteristics of the sustainable tourism. It is tourism that meets the needs of tourists visiting tourist centers and the population. It involves ensuring and optimizing prospects for future development. The use of resources must satisfy economic, social and aesthetic needs, while maintaining cultural uniqueness, the most important ecological features, ecological species and vital systems [14]. The main directions of sustainable tourism for UNWTO are economic viability of tourist destinations, local prosperity (a high proportion of tourism in the development of a destination), quality of employment (development of the labor market) and affordable tourism (safety and comfort for tourists without any restrictions). 
It is important to distinct two interrelated terms: "sustainable tourism" and "ecological tourism".

There is still no consensus on the meaning of the terms. A common point of view to the problem is given by I. Petrasov. Ecological tourism (ecotourism) is a form (type) of tourism with certain properties. Sustainable tourism satisfies all needs and develops as to provide future generations with the same opportunities. So, any ecotourism may be called an example of sustainable tourism, while sustainable tourism may be of any other type [7]. According to the research results of TorresV. R.M. etal .; Werner K., etal., sustainable development of tourism under growing urbanization, commercialization and marketing communications allows to develop travelling and ensures integrity of destination ecosystems, maintenance of local traditions and development of local crafts $[15,16]$.

The characteristics that quite fully show the essence of sustainable tourism are:

- sustainable use of natural and cultural potential based on a program-targeted approach to the development of tourism;

- transition of enterprises of the tourism industry to resource-saving technologies;

- involvement of the population in making decisions on the directions of tourism development in detached territories;

- partnership of the public and private sectors;

- promotion of tourism to the socio-economic rise in territories [17].

The characteristics relate to legal, environmental, economic, social, cultural and ethnic aspects of the interaction of subjects in course of tourism activities, state regulation of the tourism industry, provision of services to tourists.

The foregoing shows that sustainable tourism is outside of any classifications of tourism and is significant from a legal, economic, or a public relation sphere point of view.

However, a compromise of views and opinions on the importance of the concept may be considered only if the significance is prescribed by a rule of law. So, the point of view of N.V. Shabanova is worth noticing. A prerequisite for sustainable tourism development is the development and improvement of the regulatory framework in the sphere of tourism. [18].

Thus, the support and development of sustainable tourism is necessary at the level of regulatory legal acts regulating public relations in tourism, i.e state programs:

- in the Russian Federation - the Strategy for the development of tourism in the Russian Federation for the period up to 2035, approved by the order of the Government of the Russian Federation as of September 20, 2019 No. 2129-r, the Concept of the federal target program for the "Development of domestic and inbound tourism in the Russian Federation (2019-2025) , approved by the order of the Government of the Russian Federation as of May 5, 2018 No. 872-r, as well as the Federal target program "Development of domestic and inbound tourism in the Russian Federation (2019 - 2025)" approved by the Federal Tourism Agency, regional programs for the development of tourism in the constituent entities of the Russian Federation;;

- in the Republic of Belarus - the state tourism development program adopted every five years by the Council of Ministers of the Republic of Belarus, and tourism development programs in the regions and the city of Minsk, approved by local Councils of Deputies.

\section{Conclusions}

In our opinion, the initial task is to amend the national laws regulating tourism, i.e. to include the definition of "sustainable tourism" and supplement the principles of state regulation of tourism with the need to ensure sustainability in tourism. It is suggested to do the following: 
1. To supplement the Article 1 of the Federal Law of the Russian Federation "Concerning the Fundamental Principles of Tourist Activities in the Russian Federation" and the Art. 1 of the Law of the Republic of Belarus "Concerning Tourism" with the sentence: "sustainable tourism is tourism that meets the needs of both tourists visiting tourist centers and the population of tourist destinations themselves, providing prospects for the future development of touristic territories, when tourist resources are used in such a way as to satisfy various the needs of tourists, while maintaining cultural uniqueness, the most important ecological features of the territories and vital systems. "

2. To In Article 3 of the Federal Law of the Russian Federation "Concerning the Fundamental Principles of Tourist Activities in the Russian Federation", referred to as "Principles of State Regulation of Tourist Activities", the principle written after the words "The State, recognizing tourist activities as one of the priority sectors of the economy of the Russian Federation," shall be stated as follows : "Promotes tourism activities and creates favorable conditions for the sustainable development of such activities and tourism in general; ...".

3. To add the words "promoting sustainable development of tourism with minimization of its consequences for the environment; ... " after the words "The main principles of state regulation in the field of tourism are:" in the Article 5 of the Law of the Republic of Belarus "Concerning Tourism", called "Basic principles of state regulation in the field of tourism".

The amendments and additions would ensure the consistent introduction of the definition of "sustainable tourism" and the principle of sustainable tourism development in various regulatory legal acts of the Russian Federation and the Republic of Belarus. That would reduce legal uncertainty in the sphere and be an additional guarantee for sustainable development.

It should be noted that the Article 2 of the Treaty on the Eurasian Economic Union contains the term "harmonization of legislation". The term means the approximation of the legislation of the Member States aimed at establishing similar (comparable) regulations in certain spheres [19]. The changes suggested would enable further harmonization of the legislation on tourism of the EAEU member states. The states are the Republic of Belarus, the Russian Federation, Armenia, Kazakhstan and Kyrgyzstan. The perspective is quite real regarding the existing types and characteristics of the tourist infrastructure that was created in the last century as a single global complex of recreation and tourism.

The amendments and additions suggested are also an integral part of the process of implementation of the norms of international law into the national legislation of the Russian Federation and the Republic of Belarus in terms of sustainable development, i.e. sustainable development of tourism.

\section{References}

1. O.V. Pirogova, O.Yu. Pirogov, Int. J. of Applied and Basic Res., 7-2 (2017)

2. RIA NOVOSTI, https://ria.ru/20200728/1575052058.html

3. C. Dagman, Bulletin of Belgorod University of Cooperation, Economics and Law, 4(71) (2018)

4. Voluntary National Review of the Implementation of the 2030 Agenda for Sustainable Development, https://sustainabledevelopment.un.org/content/documents/26421VNR_2020_Russia_R eport_Russian.pdf.

5. World Environment Strategy, URL: http://wwwgreensalvation.org

6. The Hague Declaration, http://docs.cntd.ru/document/901737419 
7. I. Petrasov, Concept of Sustainable Development as Applied to World Tourism (2010)

8. A.V. Polukhina, Innovative development of the economy, 5-2 (2019)

9. S.V. Smirnov, Academic journalism, 2 (2020)

10. E.V. Moshnyaga, Bulletin of RMAT, 9 (2013)

11. I. N. Yakhnovets, Civil law regulation of inbound and domestic tourism in the Republic of Belarus: dis. ... Cand. jurid. Sciences (2012)

12. E.M. Maksarova, Izv. Ross. state ped. un-ta them. A.I. Herzen, 85 (2008)

13. E.G. Telicheva, Formation of trends in sustainable development of tourism enterprises in the region: monograph (2019)

14. A.Yu. Alexandrova, International Tourism (AspectPress, 2004)

15. V. R.M. Torres, A.S. Lorenzo, S. J. Castro et al., J. of science and technology policy management, 10(4) (2019)

16. K. Werner, K.M. Griese, C. Bosse, J. of sustainable tourism, 0021 (2020)

17. O.S. Shimova, Sustainable Tourism (2014)

18. N.V. Shabanova, Business management. XVII Intern. scientific and practical. Conf. (2019)

19. Treaty on the Eurasian Economic Union, http: //docs.cntd.ru/document/420205962 